\title{
INDONESIA-FIJI BILATERAL RELATIONSHIP DEVELOPMENT THROUGH SOUTH-SOUTH COOPERATION IN 1999-2016
}

\author{
Hanna Ladrika Precillia \\ International Relations, Universitas Kristen Indonesia, Jakarta, Indonesia \\ hannaladrika@gmail.com
}

\begin{abstract}
The use of soft power in diplomacy is essential because it minimizes the use of violence and coercion to solving a problem. This strength became the primary tool in the diplomacy of Indonesia-Fiji bilateral relations. The implementation of Indonesia's soft power is Indonesia's engagement in South-South Cooperation through technical cooperation for Fiji. This training is considered essential for Indonesia's national interest, such as to support the territorial integrity and Indonesia's position in the South Pacific. The problem in this research is how the development of bilateral relations between Indonesia-Fiji through South-South Cooperation in 1999-2016? What is the impact of South-South Cooperation that Indonesia has made with Fiji? The research method used is qualitative with collecting data and uses the concept of Soft Power, Bilateral Relations, and International Cooperation Theory. Indonesia's bilateral relations with Fiji over the period of 1999-2016 have increased. The increase can be seen from the position of the total ranking of Fiji trade with Indonesia, which always occupies the top three in the South Pacific region. The Indonesian Government's strategy to improve bilateral relations with Fiji is to use a soft power approach in the form of technical cooperation within the South-South Cooperation Framework. This strategy has a positive impact on the political and economic fields of Indonesia. In politics, Indonesia has gained political support from Fiji about Indonesia's territorial integrity from the separatist movement. In the area of economy, Indonesia has succeeded in opening up a new market in the agriculture sector that is selling hand tractors to Fiji and Vanuatu.
\end{abstract}

Keywords: Bilateral Relations, Indonesia-Fiji, South-South Cooperation, Technical Cooperation.

DOI: 10.33541/sp.v19i1.1645

Sociae Polites : Majalah IImiah Sosial Politik

Faculty of Social and Political Science, Universitas Kristen Indonesia

ISSN 1410-3745 print/ ISSN 2620-4975 online

Volume 19, Number 1 (January - June 2018)

Pages 18-32 


\section{Introduction}

\subsection{Background}

International relations is an interaction or cooperation between countries carried out to meet the national interests of many natiosn. Also including aspects of ideology, legal politics, economics, social, culture, and defense and security - that cross national borders between state actors, both governmental and non-governmental, including the study of relevant conditions surrounding interactions said "(Yani 2011, 8). The pattern of international relations during World War I until the Cold War is still state-centric in which the country is still the main actor in international relations (in a sense, even bipolar). The war that occurred then influenced the prevailing global system. Changes in the international system that occur change the sources of power in international relations.

During World War I to the Cold War, the source of strength in international relations focused on hard power, namely the ability of the state to influence the opposing party by using violence and threats (Ashari 2015, 220). In its development, global power is no longer limited to hard power, which only focuses on military aspects. The strength of a country must be attractive compared to the coercive approach of culture, political ideology, and policy. In this context, the intended power referred to as soft power (Meyer 2007). The emergence of soft power as a source of strength in the international world has implications for the implementation of a country's diplomacy. According to Joseph Nye, soft power is the ability to get what you want through attraction rather than through coercion or payments (Nye 2008, 94). This ability did co-opt other actors without using military threats or by offering rewards.

The form of soft power that continues to develop is through South-South Cooperation (SSC) involving developing countries. SSC, in general, is the process of cooperation between two or more developing countries in achieving goals together through collaboration in the exchange of science, information, resources, and technology (Chahoud 2007). Also, the SSC aimed at developing fellow developing countries to build collective independence, which will strengthen the position of developing countries in international forums (Choesni 2014). SSC was born from the background of newly independent third world countries to increase their capacity after the end of World War II. After the end of World War II, many emerging third world countries which have problems due to the war that occurred.

Recognition of newly independent third world countries has become a significant focus on working together to meet the national needs of third countries from the woes that have resulted from the war. At that time, Indonesia was also part of a newly independent third world country. Since the beginning of its independence, Indonesia has begun to commit to cooperating with third world countries as a form of solidarity among third world countries. Soft power is a source of strength for Indonesia in doing work the same among third world countries. One of the forms of implementation of Indonesian soft power is by participating in the SSC. The SSC, in its application, took the way of providing technical cooperation to developing countries such as providing capacity building training, sending experts to provide training, and delivering goods grants. Until now, Indonesia has provided technical cooperation to developing countries (K. L. Negeri, Technical Cooperation 2012). The recipient countries of Indonesian technical cooperation are spreading across the continents of Asia, Africa, the Pacific, and Latin America. 
The existence of SSC through cooperation techniques can strengthen Indonesia's position internationally and establish good relations with recipient countries. Indonesia is no longer just a beneficiary country but also a new donor country for other developing countries. South Pacific is an area that is one of the priorities for employment, the same technique from Indonesia. In the early 1980s, Indonesia began to make the South Pacific nation as its foreign policy. It reinforced by a statement from the Indonesian Foreign Minister, Ali Alatas, who stated that the South Pacific region was one of the priorities for Indonesia's different implementation (Bantarto 1994, 189). Fiji is a country that is also a priority for the granting of Indonesian technical cooperation. Good bilateral relations between the two countries have existed since 1974, marked by the opening of diplomatic relations between Indonesia and Fiji.

The existence of Fiji itself is essential for Indonesia because Fiji has a durable power among the countries in the South Pacific region. They evidenced by Fiji's involvement in various forums in the South Pacific region such as the Pacific Islands Forum (PIF), Pacifics Islands Development Forum, and Melanesian Spearhead Group (MSG). Fiji's influential role in the forum can be an advantage for Indonesia to establish and maintain good relations with other South Pacific countries. Good relations between the two countries have a good influence on political and economic cooperation. The strategy of the Indonesian Government in implementing soft power is to provide workers the same technique with Fiji in the form of capacity training. The provision of technical cooperation within the SSC framework provided by Indonesia expected to improve bilateral relations with Fiji.

\subsection{Research Question}

This journal raised the development of bilateral relations between the two countries, which was strengthened by South-South Cooperation for Fiji, which carried out as a form of Indonesian soft power. Based on these thoughts, the research questions is how the development of bilateral relations between Indonesia and Fiji through SouthSouth Cooperation 1999-2016?

\subsection{Purposes and Objectives}

This journal intended to see the soft power implemented by the Indonesian Government in the form of South-South Cooperation. The results to achieve in this journal are to see the development of Indonesia's bilateral relations with Fiji between 1999-2006 within the framework of the SSC. The strategies are being carried out by the Government of Indonesia in implementing the diplomas. Also, to improve the development of relations between the two countries from year to year.

The benefit theoretically is to give a thought or broaden insight about concepts, theories to the science of international relations. Whereas the practical benefit obtained is to provide information about the development of interactions carried out by countries today. Describes South-South Cooperation and explains the events and achievements and strategies pursued by Indonesia through South-South Cooperation in enhancing bilateral relations with Fiji.

\section{Literature Review}


International relations are closely related to cooperation relations between countries. Cooperation is carried out by a state to achieve its private interests. According to Kartasasmita, international cooperation is a necessity. As a result, the existence of interdependence and the increasing complexity of human life in the international community (Kartasasmita 1997, 20). Every country in the world cannot live alone or alone. In solving problems and in fulfilling the needs of his country, the role of other countries needed to help him. Fiji is a developing country located in the South Pacific, which needs help from the country others like Indonesia to increase domestic capacity. Government conditions in Fiji often experience coups, and the impact of the coup that occurred made Fiji ostracized from commonwealth countries and the United States, who considered the Fiji government undemocratic (Salim 2014, 8). Such isolation has an impact on the capacity building of Fiji. Indonesia sees this as trying to help Fiji become more democratic by providing technical cooperation, such as inviting the General Election Commission (KPU) to give a presentation on the concept of one man one vote in cabinet meetings and educational institutions (Salim 2014, 34). The cooperation carried out by Indonesia is a form of solidarity between developing countries.

According to Dougherty and Robert L. Pfatlzgraff Jr. international cooperation is a relationship that not based on coercion, and the link has been legitimized, as in the United Nations or the European Union (James E. Dougherty and Robert L. Pfaltzgraff 1997, 418). It means that the cooperation carried out was born of desire and mutual agreement of both parties to meet their welfare. This understanding is appropriate when it is related to Indonesia's participation in the SSC were Indonesia, based on its desires and referring to the 1945 Constitution, felt the need to do this cooperation to help other developing countries such as Fiji. Cooperation between Indonesia and Fiji within the SSC framework carried out without coercion from any party. Because it is part of Indonesia's foreign policy and already exists. The legitimacy that underlies such cooperation is that in the form of a Soft Power agreement popularized by Joseph Nye, which contains the ability of a country to co-opt other actors without using military threats. Country ability in influencing other countries through cooperation in forming an agenda, inviting, and carrying out positive activities to obtain the desired results (Trunkos 2013, 2).

That is, the ability can use as a tool to achieve the interests of the country. Nye said that soft power based on the ability to attract others by making friendly decisions or policies that attract other parties to get what we want. The appeal of a country to influence other states can pursue through its culture, political values, and foreign policy, which have moral strength (Nye 2004, 5). If a country can provide an excellent appeal to other countries, then by itself, the attraction can expand and spread to other countries to establish cooperation.

Soft power is more important than using hard power (Sutiono, 2012, 98). It is based on the fact that the use of hard power will cause discomfort, anxiety, and a variety of collisions, which can further stretch relations between countries while the use of soft power believed to create new opportunities to establish new networks with many countries. Soft power continues to be echoed by Indonesia in developing bilateral relations with Fiji so that it can enhance a sense of trust, brotherhood, and solidarity. The benefits that will generate can provide opportunities for Indonesia to expand its cooperation with countries other countries in the South Pacific region and can help Indonesia position internationally as a developing country that can help other developing countries. International relations in its implementation cannot be separate from 
interactions in the form of bilateral, trilateral, regional, and multilateral. Communications that are often carried out by a country in fulfilling its national interests are more bilateral.

Bilateral relations are conditions that describe the existence of a mutually influencing relationship or the occurrence of a mutual relationship between two parties. In relationships, there is a pattern of action-reaction relationships. It includes the process of the actual stimulus or policy of the initiating count. And also, the perception of the stimulus by the decision-maker in the recipient country, or response. Even, or action back from the recipient country and understanding or answer by the decision-maker of the initiating country. (Yani 2011, 42). The pattern of the action-reaction relationship looks with the asymmetrical formulation. That is, this action-reaction involves between two states in which there is a reciprocal (reciprocal) relationship. Indonesia made and issued policies aimed at increasing bilateral relations with Fiji. The Fiji government then perceived the policy actions issued by Indonesia, and based on the results of these perceptions, Fiji responded to the policies made by Indonesia. Then the response from Fiji again responded by Indonesia in the form of follow-up action. The system resulted in a collaboration between the two countries where Indonesia and Fiji had agreed to sign the cooperation that legitimized in the Development Cooperation Agreement.

\section{Research Methods}

The research method is a systematic and organized way and procedure to investigate a problem to get information to be used as a solution to the problem (Silalahi 2009, 12). The development of bilateral relations between Indonesia and Fiji through South Cooperation explained using primary data sources. Primary data sources obtained directly through field observations by following the internship process in training programs for South Pacific countries in 2016. The comments made at the Ministry of Foreign Affairs, Directorate of Technical Cooperation in the training activities program for South Pacific countries in the field of tourism. Interview activities carried out involved the staff of the Directorate of East Asia and the Pacific Ministry of Foreign Affairs of Indonesia, namely Mrs. Dyah Andrini, who understood about the bilateral relations between Indonesia and Fiji. Secondary data sources obtained by researchers, various articles, mass media, newspapers, related books, journals, official documents, and other sources. Data collection techniques used by using several methods such as interviews and official documents. Primary data sources obtained through interviews and direct observation.

While secondary data sources obtained from articles, journals, print media, books, and related official documents. Therefore, there are several forms used in qualitative research, namely document form (obtained from books in other Centers for Strategic and International Studies, Ali Alatas Library, Ministry of Foreign Affairs of the Republic of Indonesia, University of Indonesia Library, and Indonesian Christian University Library. Books and journals on South-South Cooperation, soft power diplomacy, International Cooperation Theory, Indonesian Policy in the South Pacific region, Debriefing made by the Ambassador Large Indonesia in Fiji and the Association of Basic Countries Accreditation of Representatives of the Republic of Indonesia Overseas in 2004. Official data from the Central Statistics Agency and the Ministry of Trade regarding exports and imports carried out between Indonesia and Fiji). And it forms interviews (Interviews conducted involved staff from the Ministry of Foreign Affairs, namely the Directorate of East Asia and the Pacific). 
Also, media forms (the contents of the discussion of issues in this journal also included print and online media) .1 This journal uses a qualitative approach in discussing the problems that occur. Qualitative research is descriptive analysis. Qualitative data is a source of significant and stable deviation based and contains explanations of processes which occur locally. (Silalahi 2009, 284) The data obtained are observations, interviews, photography results, document analysis, field notes, compiled by researchers at the research location. This research method can help in explained the development of bilateral relations between Indonesia and Fiji that used soft power and the effects arising from the cooperation carried out by Indonesia through the provision of the technical agreement for Fiji.

\section{Results and Discussions}

\subsection{Bilateral Relations Indonesia-Fiji}

Fiji is a republic located in the southern Pacific Ocean. It consists of 322 islands, of which 106 are uninhabited, and 522 other smaller islands. Fiji has 2 (two) most essential islands, Viti Levu and Vanua Levu. Viti Island Levu is a vital island where the capital is on the island. The capital of Fiji is Suva. About 3/4 of Fiji's population lives on Viti Levu Island. Fiji's area is only 18,274 km2 (CIA 2017) and has a population of 915,303 people (BNP2TKI 2017).

Socio-culturally, Fiji is part of the Melanesian subregion. Initially, Fiji was a country that was in the British territory in 1874. From 1879 to 1916, the British brought Indian citizens to come to Fiji to work as sugar cane plantations and settle into Fiji citizens (Policies 2004, 281). The population of Indian descent in Fiji reaches $48.2 \%$ of the total population of Fiji. On October 10, 1970, Fiji gained its independence from Britain and became a member of the Commonwealth (Fiji n.d.).

At the beginning of its independence, Fiji had the official name of the Sovereign Democratic Republic of Fiji. But in 1997, a constitution called the 1997 Constitution (amendment 1990) was adopted. And which changed the official name of the state of Fiji into the Republic of the Fiji Islands. Fiji is an island nation with a small area. Due to these limitations, Fiji is trying to implement a look north policy aimed at maintaining good relations and cooperation with neighboring countries in the Pacific region South and build and enhance good relations with countries in the Southeast Asian region. The principles adopted by Fiji in carrying out its foreign policy are respecting the sovereignty and territorial integrity of a country, non-intervention, the spirit of brotherhood and friendship, rules of law, good governance, consensus building, dialogue, and solidarity among developing countries (Policies 2005, 5 ).

Implementation of politics abroad, Fiji opened diplomatic relations with Indonesia in 1974 in the hope of establishing good cooperation in various fields to increase Fiji's economic income and support political cooperation between countries in the South Pacific region and countries in the Southeast Asia region. Bilateral relations between Indonesia and Fiji began in 1974. Fiji opened its bilateral ties with Indonesia precisely four years after gaining its independence from Britain in 1970. The opening of diplomatic relations that have existed since 1974 did not significantly affect the focus of Indonesia's foreign policy to the South Pacific region. For Indonesia, the South Pacific region is an area that is considered not to be a source of threat to the national security of Indonesia. 
The South Pacific Region is the backyard of Indonesia, where the focus of Indonesia at that time was more directed towards the countries located in the front yard of Indonesia. The focus of Indonesia's foreign policy is still on countries big companies such as the United States, Japan, Western Europe, and other countries in Southeast Asia. In the 1980s, Indonesia began to shift its foreign policy focus towards the South Pacific region and began to increase its bilateral relations with the South Pacific countries, Fiji. The reason Indonesia shifted its foreign policy focus to Fiji was that the island nation was active in joining significant forums in the South Pacific region such as the Melanesian Spearhead Group (MSG) and the Pacific Island Development Forum (PIDF). The existence of a PIDF secretariat center in Suva makes Fiji an influential country in the South Pacific. In the UN, there is a principle of one country one vote, Fiji as a member state of the UN, also has a voice in it.

It makes Fiji a country that has an economic and strategic value for Indonesia to develop sustainable development cooperation and help Indonesia to keep the integrity of the Unitary Republic of Indonesia from the separatist movement in Papua. Political cooperation between Indonesia and Fiji can look through state visits conducted by the two countries. In 2011, the Fiji government made 2 (two) visits, represented by the Prime Minister of Fiji (Josaia Voreqe Bainimarama) and the Fiji Foreign Minister (Ratu Inoke Kubuabola) to conduct the opening of the Fiji Embassy in Jakarta and the signing of the Development Cooperation Agreement in Bali.

The second visit was made by the Minister of Foreign Affairs of Fiji (Ratu Inoke Kubuabola) in the context of the appointment of the Foreign Ministers and Deputy Melanesians Spearhead Group (MSG) to Indonesia; The visit of the Fiji President to Indonesia (Ratu Epeli Nailatikau) in 2014. In 2016, the Fiji government returned to a working visit represented by the Fiji Minister of Foreign Affairs (Ratu Inoke Kubuabola) on March 22, 2016, to attend the Regional Ministerial Conference of the Bali Process on People Smuggling, Trafficking in Persons and Related Transnational Crime (BRMC) VI in Nusa Dua, the Balidan Minister of Defense of Fiji (Ratu Inoke Kubuabola) on October 31 to November 4, 2016, was a working visit and attended the Indonesia Defense Expo in Jakarta. On 17-19 June 2014, the 6th President of Indonesia, namely President Susilo Bambang Yudhoyono, visited Fiji. It became the first Indonesian president to visit Fiji and become chief guest (the primary guest) at The Pacific 2nd Summit Islands Development Forum (PIDF) held in Fiji. On March 1, 2015, the new Indonesian Minister of Foreign Affairs Retno L.P Marsudi made his first visit to Fiji to renew the commitment of cooperation between the two countries to improve relations and contribute to the development with countries in the South Pacific. The foreign ministerial meeting was held again at the Joint Ministerial Commission (JMC), which held on September 1, 2015, in Suva, Fiji (Embassy of the Republic of Indonesia in Suva 2015).

Foreign Minister Retno L.P Marsudi represented Indonesia. The meeting was a form of continuation of Development The Cooperation Agreement (DCA) agreed upon in 2011. Indonesia's visit to Fiji was held again on March 31, 2016, led by the Coordinating Minister for Politics, Law, and Security Luhut B. Padjaitan. The series of work visits to further reinforce Indonesia's commitment to continue working with Fiji in the economic, fisheries, agriculture, military, and cultural fields. Discussion of the MSG issue colors the meeting between Minister Luhut B. Padjaitan with Foreign Minister Ratu Inoke Kubuabola. Fiji has the initiative to raise the status of Indonesia's position at MSG from an associate member to a full member (Paskalis 2016). The approach through state visits provides a positive result for the two countries to continue to work together. The 
appointment of high officials and the assistance provided are part of the implementation of Indonesia's soft power.

Economic cooperation is also an essential aspect of Indonesia-Fiji bilateral relations. The opening of the Indonesian Embassy in Suva has opened new opportunities for Indonesia to enhance economic ties to Fiji further. Indonesian Foreign Minister Retno L.P Marsudi said that Fiji is one of Indonesia's largest trading partners in the South Pacific region (Alvionitasari 2016). The total trade between Indonesia and Fiji that occurred in the 1999-2016 period ranked second after Papua New Guinea. It proves that Fiji is a valuable trading partner for Indonesia.

Seeing the total trade between Indonesia and Fiji began in 1999-2016, Fiji has always been in the top 3 compared to other South Pacific countries. Fiji is a country in the South Pacific that has a strategic position which located in the middle of the South Pacific region. It very much used by Indonesia to reach markets in Fiji. The level of consumption of the sizeable Fijian community and less diversified domestic products can be an opportunity for Indonesia to sell its products to Fiji. In 1999 Indonesian exports to Fiji reached USD 10.87 million and continued to increase until 2005, which reached USD 20.19 million. In 2006 Indonesia's export activities to Fiji decreased from USD 20.19 million to USD 17.67 million. In 2007 Indonesian exports experienced a slight increase of US \$ 18.75 million and continued to increase until 2009. In 2006 the inflation reached USD 25.27 million, and in 2009 Indonesian exports to Fiji experienced significant growth and is the highest export value achieved by Indonesia, reaching USD 42.88 million. Commodities exported to Fiji include light vessels, buoys, soaps, discuss cotton, detergents, and paper. After experiencing such a significant increase, Indonesia-Fiji export activities experienced a sharp decline. In 2010, the export value obtained by Indonesia only reached USD 18.03 million. The decrease can occur because of the lack of demand and delivery of goods due to lousy weather constraints.

In 2011 Indonesian exports to Fiji began to rise again at USD 21.36 million. In the range of 2012 to 2016, Indonesia's export value experienced ups and downs. In 2012 alone, trade figures from Indonesia to Fiji reached USD 25.37 million. This figure shows an increase compared to 2011. Furthermore, in 2013, Indonesia's exports declined again at USD 23.55 million and continued to decline in 2014, which was USD 22.26 million and in 2015, which was USD 20.52 million. However, in 2016 Indonesia's export numbers to Fiji increased to reach USD 27.82 million. Some Indonesian products that enter Fiji get great interest in the Fiji market. Indonesian products that are in demand in Fiji include paper products, textile fibers, electrical appliances, household appliances, clothing, snacks, coffee. Also, daily necessities, plastic products, shampoos, bath soaps, detergents, products - chemical products, and manufacturing equipment (cars and agricultural equipment) (Information 2017).

The amount of Indonesian imports from Fiji is not as large as the value of exports from Indonesia to Fiji. In the range of 1999 to 2002, Indonesia's import value only reached an average of US \$ 1 million. In 1999 the import value from Fiji was USD 1.05 million. In 2000, USD 1.14 million, then in 2001 it reached USD 1.88 million, and in 2002 it was USD 1.63 million. The following year in 2003, it reached USD 2.63 million. In 2005 the value of Indonesia's imports from Fiji began to experience a rapid increase of US \$ 7.93 million. The commodity imported by Indonesia in 2005 was cane sugar. This value is the most significant import value during 1999-2005. The declining cost of Indonesian imports occurred in the range of 2006-2009. In 2010-2014 the value of Indonesia's imports continued to increase, especially in 2014, reaching USD 3,306 million. Furthermore, in 
2016 the number of Indonesia's imports from Fiji increased by USD 1.22 million compared to the previous year, which did not reach one million US $\$$. The primary commodities imported from Fiji to Indonesia are sugar, leather products, wood products, office equipment, and several other types of manufactured products.

\subsection{South-South Cooperation}

South-South Cooperation is a development cooperation between developing countries to achieve mutual independence based on solidarity, equality, and mutual benefit (T. K. Indonesia 2017). KSS term used after the issuance of UN Resolution No.58 / 220 in 2003, which contained the High-Level Committee on South-South Cooperation and the designation of December 19 as UN Day for South-South Cooperation. Before known as the KSS, this collaboration was better known as Technical Cooperation between Developing Countries (KTNB). The emergence of the SSC is inseparable from the similarities in the backgrounds of countries developing. It bases on the desire of developing countries to be more independent in increasing development growth in their respective countries. At the beginning of its emergence, the SSC is a form of solidarityraising activities that emphasize the benefits of developing countries. Then, the SSC is moving towards economic cooperation activities and development growth to catch up and drive the competitiveness of developing nations.

Implementation of SSC through the provision of technical cooperation, technical cooperation is one tool that supports Indonesia's diplomacy efforts in bilateral, regional, and international forums (K. L. Negeri, Technical Cooperation 2012). The original form of cooperation The technique is in the way of capacity building training, sending experts, providing scholarships and internships, as well as goods grants. Indonesia's activeness in the SSC provides benefits for Indonesia's national interests, including federal benefits obtained by Indonesia. It is maintaining national security stability, increasing bilateral relations between Indonesia and other countries. Also, making the SSC a tool of Indonesia's economic diplomacy in achieve national development goals and increase national economic development by carrying out trade and investment to Southern countries and promoting cultural values that Indonesia has. The implementation of the SSC by Indonesia is a form of soft power that has been formulating in Indonesia's foreign policy, such as during the reign of Indonesia's 6th President Susilo Bambang Yudhoyono, who used soft power as a source of strength to implement a look east policy strategy. In the era of Joko Widodo's leadership, the development of southern countries had poured into the first grind of laughter, stating Indonesia's role in enhancing South-South development cooperation. 


\subsection{South-South Cooperation in the South Pacific and Fiji}

South Pacific is a region that is next to Indonesia. The characteristic of the South Pacific region is that its resources are only human, land, which is both minimal in number and marine resources, which is large (Habib 1997). This region consists of 16 Pacific Islands Forum member countries including Australia, Cook Islands, Federated States of Micronesia, Fiji, Kiribati, Marshall Islands, Nauru, Niue, Palau, Papua New Guinea, Samoa, New Zealand, Solomon Islands, Tonga, Tuvalu, Vanuatu (K. L. Indonesia n.d.). There needs to be more attentive to the region to support Indonesia's presence in the South Pacific region. In enhancing bilateral relations with the South Pacific countries, Indonesia is always trying to increase its intensity and extension by implementing technical cooperation within the SSC framework. Indonesia made South Pacific countries as professional cooperation partners because this area has a very strategic value. In terms of location, Indonesia and South Pacific countries are countries that share a wide field of waters and have similarities in climate and marine resources. Not surprisingly, Indonesia and The South Pacific share a variety of experiences through capacity building within the SSC framework. Also, Indonesia wants to expand and increase trade with other countries.

South Pacific countries. Indonesia's SSC is in the form of providing technical cooperation such as capacity building training, sending experts and grants, or providing equipment daily needs. The increasing number of technical assistance and grants for daily necessities provided by Indonesia to the South Pacific can give an understanding of the quality of products manufactured in Indonesia. Provision of cooperation the techniques supplied by Indonesia continue to carried out sustainably. Indonesia's strategy to increase economic opportunities in the South Pacific is to look more closely at the needs that they need after the provision of technical cooperation. Through training provided by experts from Indonesia, it expected that these countries could apply it in their daily lives when the application is successful and has increased, so tools are needed, as explained in the training so that they will improve the demand for purchasing products from Indonesia. The increased demand indicates satisfaction with the products produced by Indonesia and creates a dependency between the South Pacific countries on Indonesia.

The cooperation carried out is included in the framework of the SSC. Through the soft power carried out by Indonesia through the provision of technical agreement within the context of the SSC makes Indonesia's presence in Fiji felt real. Visits, professional collaboration, and gifts tangible assistance provides a positive perspective on Indonesia. The technical cooperation undertaken is one of the diplomatic tools to improve Indonesia's bilateral relations with Fiji. The number of technical cooperation awards that have been giving as many as 131 programs. Also, attended by 600 participants from Fiji (Engineering 2016). Form of granting technical cooperation in which 131 applications have been awarded and attended by 600 participants from Fiji (Engineering 2016).

The type of providing technical assistance. Such as providing training in the field of marine and fisheries, democracy, tourism. Besides, the Government of Indonesia also assists in the form of scholarships and internships as well as goods grants, namely hand tractors. The provision of technical cooperation provided has had a positive impact on bilateral relations between Indonesia and Fiji, evidenced by the political support expressed by the Government of Fiji. The support stated by the Fiji Foreign Minister (Ratu Inoke Kabuabola) and the Prime Minister of Fiji (Josaia Voreqe Bainimarama), where the Prime Minister of Fiji expressed support for Indonesia at the MSG Summit meeting in Honiara, Solomon Islands. In his statement, the Fiji PM said that for Fiji 
Indonesia's sovereignty over Papua and West Papua in 2015. Then in 2016, the Minister of Defense and Security of Fiji (Ratu Inoke Kabuabola) and the Minister of Foreign Affairs (Josaia Voreqe Bainimarama) reiterated Fiji's position of continuing to support the territorial integrity of the Republic of Indonesia.

In addition to impacting political support, technical cooperation undertaken by Indonesia has opened up new opportunities for the economic sector. The training and capacity building provided to Fiji is part of the promotion of Indonesia's excellence. Development through training from experts and product excellence owned by Indonesia can be used as the initial capital to widen the broader Indonesian market in Fiji and other South Pacific countries. The provision of technical cooperation that is always done aims to improve the skills of the people of Fiji to produce better production goods and can later use as Indonesian trade partners. The training provided by experts from Indonesia provided a lesson for the Fijian community in managing a food ingredient as well as in producing an item, and later the goods produced could be purchased by Indonesia and Fiji at a more affordable price. The agricultural training program and hand tractor grants that have been giving produce a positive result for the Indonesian hand tractor production market. Fiji and Vanuatu are interested in buying Indonesian hand tractors and is interested in marketing Indonesian-made products in the South Pacific region. The purchase illustrates the success of providing technical cooperation conducted by Indonesia. Continuing training followed by goods grants can have a positive impact on Indonesia.

\section{Conclusions and Recommendations}

\subsection{Conclusions}

Bilateral relations between Indonesia and Fiji have improved with the implementation of South-South Cooperation, which carried out from 1999 to 2016. Cooperation between the two countries is based on the principle of trust and without coercion. The form of cooperation is part of the results of the agreement between the two countries. It is an implementation of the International Cooperation Theory, which explains that the cooperation carried out by Indonesia and Fiji is not based on coercion or threats but was born from the agreement of both parties to both meet their national interests. This cooperation has been legitimizing in the Development Cooperation Agreement. The political cooperation relationship between Indonesia and Fiji can Look from active state visits from 2011 to 2016 . While economic cooperation, Fiji's total trade with Indonesia in the last five years occupies the top three positions of the 16 other South Pacific countries. Papua New Guinea occupies the first position and in the third position is occupied by Ameican Samoa and followed by the Marshall Islands and the Solomon Islands.

It proves the relationship of dependence from Fiji on Indonesian goods. This SSC program strengthens international cooperation between the two countries. The original form of SSC carried out by Indonesia for Fiji is in the form of technical work. Indonesia did this as a form of the seriousness of the Government of Indonesia in implementing its policies in the South Pacific region, especially for the country Fiji. Some of the focus of providing technical cooperation in Indonesia is training for the Fiji government in organizing a government that carries good governance in the field of marine and fisheries, agriculture, and tourism. It Indonesia's strategy to further strengthen bilateral relations 
between the two countries in the political and economic fields. Indonesia needs Fiji, given Fiji's strategic position in the South Pacific region. Fiji is one of the key entities in the South Pacific region that has a large influence.

The forms of technical cooperation provided by Indonesia to Fiji are capacity building training, sending experts, granting scholarships and apprenticeships, and goods grants. From 1999 through 2016, Fiji has received 131 training programs conducted by Indonesia in various sectors. Technical cooperation provided by Indonesia in the political field, namely the provision of capacity building training for the Government, parliament, and academics Fiji regarding the democratic system adopted by Indonesia in running its Government. Indonesia carried out this strategy to seek support from Fiji for West Papua to remain within the territory of the Republic of Indonesia.

The issue is one the main agenda in forums in the South Pacific where South Pacific countries such as Vanuatu and the Solomon Islands often support the separatist movement and its sympathizers to free West Papua from Indonesia. Prime Minister Josaia Voreqe Bainimarama conveyed Fiji's support of the territorial integrity of the Republic of Indonesia during a meeting of high officials at the MSG forum in the Solomon Islands in 2015 as well as Fiji's Foreign Minister Ratu Inoke Kubuabola. The existence of Fiji's support for the integrity of the Republic of Indonesia is proof that bilateral relations conducted through the soft power approach in the SSC program (technical cooperation) have been successfully carried out by Indonesia. Fiji's attitude to continue to support and respect the integrity of the Unitary Republic of Indonesia indicates that there is an increase in bilateral relations between the two countries. The attitude shown by Fiji towards Indonesia is the application of the concept of bilateral relations in which interactions between countries need to be base on the principle of mutual respect for the rights of the two countries.

Fiji has established a bilateral relationship well with Indonesia with this support. An important position owned by Fiji in the MSG, PIF, and "tPIDF" forums provided a good opportunity for Indonesia. The Fiji Voice is one of the important points that can use as a strategy for Indonesia to influence the South Pacific countries to continue to support Indonesia's position and the territorial integrity of the Republic of Indonesia. The provision of technical cooperation is also part of Indonesia's economic cooperation on Fiji, which had a positive impact on Indonesia's economic relations with Fiji. Evidenced by the provision of capacity building training for Fijian farmers opens the opportunity for the Indonesian hand tractor market in Fiji. The training taught Fijian farmers to use Indonesian-made hand tractors. The Indonesian Government's strategy did not stop with training, but in 2010, the Government gave ten hand tractors to Fiji, and in 2016 there were 100 .

The follow-up of the capacity building training followed by the provision of hand tractors paid off for Indonesia, where Fiji was interested in buying tractors from Indonesia and wanted to market hand tractor made in Indonesia in the South Pacific region. The diplomacy carried out within the framework of the SSC is a form of soft power implemented by the Government of Indonesia. It's essential to increase the existence and position of Indonesia for Fiji and in the South Pacific region. The approach of using soft power can create dependence on Fiji and other South Pacific countries in Indonesia. Through this approach, it can provide a sense of confidence in these countries to cooperate with Indonesia in the political and economic fields.

\subsection{Recommendations}


- Further improvement gives to technical cooperation for Fiji. The provision of technical assistance can continue to increase Fiji's political support for the territorial integrity of the Republic of Indonesia and can create Fiji's dependence on Indonesia. This dependence can have a positive impact on Indonesia's position in the South Pacific region.

- Indonesian diplomacy needs to improve against forums in the South Pacific, such as MSG and "PIDF." The existence of diplomacy can help Indonesia get international support, such as support for the integrity of the Unitary Republic of Indonesia from the separatist movement OPM.

- The priority program of technical cooperation between Indonesia and Fiji needs to be follow up with the provision of goods grants to support the continuation of the technical assistance that has given. Granting goods grants can open opportunities for Indonesian exports.

- Providing training in the field of fisheries must continue to be done to increase Fiji's dependence on products based on fish and seaweed and increase Indonesia's exports to Fiji.

- The opening of the Seaweed Center and the Center for Crackers conducted by Indonesia can continue to be followed up by the Ministry of Maritime Affairs and Fisheries and in collaboration with the Ministry of Foreign Affairs. To continue to improve the capacity of the Fijian community by processing seaweed and also crackers. The later results can import into Indonesia at an affordable price and according to Indonesian standards. The follow up can be in the form of training, which continues to carry out at the Seaweed Center and Crackers Center.

- Investments in marine and fisheries need to increase in terms of providing marine products for Fiji and seeing the seeds of Indonesian exports to Fiji. It can be taken into consideration to increase economic cooperation between the two countries. 


\section{BIBLIOGRAPHY}

\section{Books}

Ashari, Khasan. 2015. Kamus Hubungan Internasional. Bandung: PT Nuansa Cendekia.

Bandoro, Bantarto. 1994. Hubungan Luar Negeri Indonesia Selama Orde Baru. Jakarta: Centre for Strategic and International Studies.

Dougherty, James E dan Robert L. Pfaltzgraff, Jr. 1997. Contending Theories of International. New York: Longman.

Habib, A. Hasnan. 1997. Kapita Selekta: Strategi dan Hubungan Internasional. Jakarta: Centre for Strategic and International Studies.

Meyer, M., 2007. An Exploration of the Role of Soft Power in Hegemony: the USA and China. South Africa: University of Stellenbosch.

Salim, Aidil Chandra interview oleh Badan Pengkajian dan Pengembangan Kebijakan Kementerian Luar Negeri Republik Indonesia. Kepentingan Indonesia di Fiji dan Kawasan Pasifik pada umumnya (April 24, 2014).

Trunkos, Judit. 2013. What is Soft Power Capability, and How Does it Impact Foreign Policy. Carolina: University of South Carolina.

Yani, Anak Agung Banyu Perwita dan Yanyan Mochamad. 2011. Pengantar Ilmu Hubungan Internasional. Bandung: PT Remaja Rosdakarya.

\section{Journals}

Nye, Joseph. 2008. "Soft Power and Higher Education." The ANNALS of the American Academy of Political and Social Science. Hal .110-124.

Sutiono, Pribadi. 2012. "Soft Power dan Strategi Diplomasi Indonesia". Refleksi Politik Luar Negeri Indonesia. Vol 4 No.1. hal.98.

\section{Report}

Kementerian Luar Negeri Republik Indonesia. 2016. Data kegiatan KSST untuk Fiji. Paper, Jakarta: Direktorat Kerjasama Teknik, Kementerian Luar Negeri RI.

\section{Internet}

Alvionitasari, Rezki. Indonesia dan Fiji Perkuat Kerjasama 3 Sektor Ini. September 21, 2016. https://m.tempo.co/read/news/2016/09/21/090806214/indonesia-dan-fijiperkuat-kerjasama-3-sektor-ini diakses 11 Juni 2017.

BNP2TKI. Fiji. 9 Februari 2017. http://www.bnp2tki.go.id/read/12071/FIJI.html diakses 11 Agustus 2017.

Chahoud, T. German Development Institute. 9 2007. http://www.diegdi.de/uploads/media/9_2007_EN.pdf diakses pada 8 Maret 2017. 
Choesni, Tb. A. Kerja Sama Selatan-selatan dan Manfaatnya bagi Indonesia. Forum Group Discussion, Jakarta: Direktorat Kerjasama Pembangunan Internasional Kementerian Perencanaan Pembangunan Nasional/ BAPPENAS, 2014.

Kedutaan Besar Republik Indonesia Di Suva, Republik Fiji. Pertemuan JMC Pertama Indonesia-Fiji 2015, Sepakat Tingkatkan Kerja Sama Ekonomi. 4 September $2015 . \quad$ http://www.kemlu.go.id/suva/id/berita-agenda/beritaperwakilan/Pages/Pertemuan-JMC-Pertama-Indonesia-Fiji-Sepakat-TingkatkanKerja-Sama-Ekonomi.aspx diakses 5 Juni 2017.

Paskalis, Yohanes. Luhut: Indonesia Konsisten Hadir di Pasifik Selatan. 1 April 2016. https://m.tempo.co/read/news/2016/04/01/120758815/luhut-indonesiakonsisten-hadir-di-pasifik-selatan diakses 7 Juni 2017. 